\title{
PENGARUH SKEPTISME, PENGALAMAN AUDITOR DAN SELF EFFICACY TERHADAP AUDIT JUDGMENT \\ (Studi Empiris pada Auditor Badan Pengawasan Keuangan dan Pembangunan (BPKP) Perwakilan Provinsi Bengkulu)
}

\author{
Wiwien Maryani ${ }^{1)}$ Fitrawati Ilyas ${ }^{2)}$ \\ Fakultas Ekonomi dan Bisnis Universitas Bengkulu ${ }^{1,2)}$

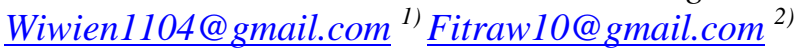

\begin{abstract}
This study aimed to examine the effect of skepticism, experience of auditors, and self efficacy on audit judgment.This research used primary data obtained by distributing questionnaires to the auditors who worked at BPKP Bengkulu province. The sample was selected using purposive sampling method. 60 questionnaires were distributed to responden (sample), but only 52 questionnaires that can be analyzed or processed. The study used Multiple Regression Analysis. The results showed that skepticism, experience of auditors and self efficacy has positive influence on audit judgment. The results of this study are expected to be taken into consideration for the representative offices Financial and development Supervisory Agency (BPKP) Bengkulu Province to give more attention about the importance of skepticism, experience of auditors and self efficacy affecting the audit judgment.
\end{abstract}

Keywords: Skepticism, experience of auditor, self efficacy, and audit judgment.

\section{PENDAHULUAN}

Pemerintah membutuhkan dana yang cukup besar dalam pengelolaan suatu Negara. Hal ini mengakibatkan diperlukannya suatu pengawasan yang cukup andal dalam pertanggungjawaban penggunaan dana untuk penyelenggaraan pemerintah. Untuk memastikan bahwa penggunaan dana telah dilakukan secara efektif dan efisien atau tidak, maka diperlukannya suatu audit. Hasil audit ini nantinya akan memberikan informasi mengenai apakah terdapat potensi kerugian Negara yang ditemukan dalam proses audit akibat dari penyalahgunaan dan inefisiensi penggunaan APBN dan APBD.

Tuntutan masyarakat akan penyelenggaraan pemerintahan yang bersih, bebas korupsi, kolusi, dan nepotisme (KKN) menghendaki pelaksanaan fungsi pengawasan dan sistem pengendalian intern yang baik atas pengelolaan keuangan Negara. Fungsi pengawasan dan sistem pengendalian intern yang baik bertujuan untuk menjamin bahwa pelaksanaan kegiatan telah sesuai dengan kebijakan dan rencana yang telah ditetapkan serta untuk menjamin tujuan penyelenggaraan pemerintah tercapai secara hemat, efisien, dan efektif.

Salah satu unit yang melakukan pemeriksaan (audit) terhadap instansi pemerintah adalah Badan Pengawas Keuangan dan Pembangunan atau disingkat BPKP. BPKP adalah organisasi yang diberikan tugas oleh pemerintah untuk memeriksa transparansi dalam pelaporan dan praktik pengelolaan realisasi anggaran sektor publik, mengawasi realisasi anggaran daerah yang 
diperoleh yang menggunakan anggaran dari pemerintah pusat dan juga bertujuan mengembangkan aspek-aspek ekonomi yang ada didaerah tersebut. Melalui pengawasan intern dapat diketahui apakah suatu instansi pemerintah telah melaksanakan kegiatan sesuai dengan tugas dan fungsinya secara efektif dan efisien, serta sesuai dengan rencana, kebijakan dan ketentuan yang telah ditetapkan.

Dalam beberapa tahun belakangan ini berbagai bentuk kecurangan dan tindakan yang melanggar aturan terkait anggaran sering terjadi pada instansi pemerintahan. Seperti kasus yang terjadi di Kota Bengkulu pada mantan Direktur Perusahaan Air Minum (PDAM) Kota Bengkulu, Ihsan Ramli yang didakwa melakukan korupsi pengadaan 540 ton tawas, dengan nilai proyek Rp. 1,755 miliar. Terdakwa dinyatakan telah menyalahgunakan wewenang dengan menunjuk rekanan secara langsung dan melakukan perbuatan melanggar hukum dengan menguntungkan diri sendiri. Perbuatan terdakwa telah merugikan Negara berdasarkan audit BPKP Provinsi Bengkulu yang menyatakan Negara telah dirugikan sebesar Rp. 528 juta (kompas.com, November 2013).

Berdasarkan kasus yang telah terjadi membuat auditor internal khususnya BPKP dalam melakukan penugasan audit harus lebih meningkatkan kinerjanya dan mempertahankan profesionalismenya. Kinerja auditor tercermin dari kualitas hasil auditnya. Auditor BPKP sebagai auditor pemerintah yang dipercayakan berdiri paling depan sebelum KPK bertindak harus lebih menjaga kualitas hasil auditnya dan selalu independen dalam bertugas agar kasuskasus yang merugikan keuangan Negara tidak mudah terjadi. Auditor dalam hal melaksanakan tugasnya melakukan penugasan audit seringkali menggunakan suatu judgment.

Hogart (1992) menyatakan bahwa judgment adalah suatu proses kognitif yang merupakan perilaku pemilihan keputusan. Dalam membuat suatu judgment, auditor akan mengumpulkan berbagai bukti relevan dalam waktu yang berbeda kemudian mengintegrasikan bukti-bukti tersebut. Audit judgment merupakan kebijakan auditor dalam memberikan pendapat untuk menentukan hasil auditnya yang mengacu pada pembentukan suatu gagasan, pendapat atau perkiraan tentang suatu objek, peristiwa, status atau jenis peristiwa yang lain. Cara pandang auditor dalam menanggapi informasi yang berhubungan dengan tanggung jawab dan risiko audit yang akan dihadapi oleh auditor sehubungan dengan judgment yang dibuatnya.

Dalam melaksanakan penugasan audit dilapangan seorang auditor tidak hanya sekedar mengikuti prosedur audit yang telah ditentukan dalam program audit, tetapi juga disertai dengan sikap skeptisme. International Standar Auditing (ISA) mendefinisikan skeptisme profesional merupakan suatu sikap auditor yang mencakup pikiran yang selalu mempertanyakan, waspada terhadap kondisi yang dapat mengindikasikan kemungkinan kesalahan penyajian, baik yang disebabkan oleh kecurangan maupun kesalahan, dan suatu penilaian penting atas bukti audit. Skeptisme adalah sifat mutlak yang harus dimiliki oleh seorang auditor untuk bisa memutuskan atau menentukan sejauh mana tingkat keakuratan dan kebenaran atas bukti-bukti maupun informasi dari klien.

Seorang auditor yang memiliki skeptisme tidak akan menerima begitu saja penjelasan dari klien yang berhubungan dengan bukti audit, tetapi akan selalu mengajukan pertanyaan untuk memperoleh alasan, bukti dan konfirmasi mengenai objek yang dipermasalahkan. Auditor harus menyadari bahwa kemungkinan akan terjadinya salah saji material bisa saja terjadi. Adanya sikap skeptisme akan lebih mampu menganalisis adanya kesalahan ataupun tindak kecurangan, sehingga auditor akan meningkatkan pendeteksian kesalahan maupun kecurangan pada proses auditing selanjutnya. 
Sikap skeptisme yang tinggi juga akan terbentuk karena adanya pengalaman yang dimiliki oleh auditor. Pengalaman merupakan suatu proses pembelajaran dan pertambahan perkembangan potensi bertingkah laku baik dari pendidikan formal maupun non formal atau bisa diartikan sebagai suatu proses yang membawa seseorang kepada suatu pola tingkah laku yang lebih tinggi. Pengalaman auditor ditunjukkan dengan jam terbang auditor dalam melakukan penugasan audit. Pengalaman kerja dapat memperdalam dan memperluas kemampuan kerja. Semakin sering seseorang melakukan pekerjaan yang sama, semakin terampil dan semakin cepat dia menyelesaikan pekerjaan tersebut. Semakin banyak macam pekerjaan yang dilakukan seseorang, pengalaman kerjanya semakin kaya dan luas, dan memungkinkan peningkatan kinerja.

Pengalaman yang dimiliki auditor sangat berperan dalam menentukan pertimbangan yang diambil oleh seorang auditor. Penelitian Jamillah, et al. (2007) melihat adanya pengaruh pengalaman auditor terhadap audit judgment yang diambil auditor. Jamillah, et al. (2007) mengatakan bahwa terdapat perbedaan judgment antara auditor yang berpengalaman dan yang tidak berpengalaman. Hal demikian dikarenakan auditor berpengalaman lebih skeptis dibanding auditor yang tidak berpengalaman.

Selain itu, disamping telah memiliki pengalaman mengaudit yang memadai karena terusterusan dihadapkan oleh pekerjaan yang sama membuat seorang auditor memiliki keyakinan diri dalam melaksanakan tugas audit. Menurut Bandura (2010) dalam Wijayantini (2014) self efficacy merupakan keyakinan seseorang terhadap dirinya sendiri akan kemampuan yang dimilikinya guna mencapai suatu hasil tertentu. Self efficacy juga merupakan persepsi seseorang sejauh mana dirinya memiliki kemampuan dan keyakinan untuk melakukan suatu aktivitas dengan hasil sesuai yang diharapkan, serta sejauh mana potensi yang ada pada dirinya. Auditor yang memiliki self efficacy yang tinggi dapat membantu dirinya menyelesaikan tugas dengan sebaik mungkin.

\section{KERANGKA TEORITIS DAN HIPOTESIS}

\section{Teori Atribusi}

Dalam penelitian ini teori atribusi digunakan untuk menjelaskan kesimpulan atau judgment yang dibuat oleh auditor. Teori atribusi pada dasarnya ingin menjelaskan mengenai penyebab dari perilaku orang lain. Apakah perilaku itu disebabkan oleh disposisi internal (misal motif, sikap, dan sebagainya) ataukah oleh keadaan eksternal (Walgito, 2002). Disposisi internal merupakan faktor-faktor yang berasal dari dalam diri individu, sedangkan keadaan eksternal berasal dari lingkungan diluar diri individu tersebut.

Dalam konteks audit, teori atribusi banyak digunakan peneliti untuk menjelaskan mengenai penilaian (judgment) auditor, penilaian kinerja, dan pembuatan keputusan oleh auditor. Atribusi berhubungan dengan penilaian dan menjelaskan bagaimana seorang auditor berperilaku. Kemampuan auditor dalam membuat judgment yang baik ditentukan oleh atribusi internal, dimana faktor-faktor yang menentukan kemampuan lebih banyak berasal dari dalam diri auditor. Kemampuan dapat dibentuk melalui usaha seseorang misalnya dengan pencarian pengetahuan, mempertahankan independensi, kepercayaan diri, meningkatkan sikap skeptisisme profesional dan juga dari pengalaman-pengalaman yang pernah ia lalui.

Kelley (1973) menyebutkan bahwa teori atribusi dapat menjawab pertanyaan mengenai persepsi sosial (social perception) namun juga sekaligus berhubungan dengan persepsi diri (self perception). Auditor ketika berhadapan dengan suatu kondisi yang janggal pada saat melakukan audit, maka dengan menggunakan faktor internal yang ada pada dirinya akan berusaha mencari 
penyebab suatu kejadian menurut persepsi individu dan cara-cara bagaimana orang memberikan penjelasan sebab-sebab terjadinya kejadian dan implikasi dari penjelasan-penjelasan tersebut. Dengan demikian, dapat dikatakan bahwa persepsi diri seorang auditor juga memainkan peranan penting dalam membuat judgment seorang auditor

\section{Audit}

Pada umumnya pemeriksaan (audit) merupakan rangkaian kegiatan pemeriksaan yang dilakukan seseorang atau kelompok yang independen dan bertujuan untuk mengevaluasi atau mengukur lembaga/perusahaan dalam melaksanakan tugas atau pekerjaan dengan kriteria yang telah ditentukan, untuk kemudian mengkomunikasikannya kepada pihak-pihak yang berkepentingan.

ASOBAC (A Statement of Basic Auditing Concept) dalam Prihandono (2012) mendefinisikan auditing sebagai berikut:

"Auditing adalah suatu proses sistematika untuk menghimpun dan mengevaluasi bukti-bukti audit secara objektif mengenai asersi-asersi tentang berbagai tindakan dan kejadian ekonomi untuk menemukan tingkat kesesuaian dengan kriteria yang telah ditetapkan dan menyampaikan hasil-hasilnya kepada pihak yang berkepentingan”.

Selain itu, menurut Agoes (2012:3), “Auditing adalah suatu pemeriksaan yang dilakukan secara kritis dan sistematis, oleh pihak yang independen, terhadap laporan keuangan yang telah disusun oleh manajemen, beserta catatan-catatan pembuktian dan bukti-bukti pendukungnya, dengan tujuan untuk dapat memberikan pendapat mengenai kewajaran laporan keuangan tersebut". Berdasarkan penjelasan diatas, dapat disimpulkan bahwa auditing merupakan serangkaian proses pemeriksaan yang dilakukan secara sistematik oleh seseorang yang independen dan berkompeten, untuk memperoleh bukti yang cukup untuk menyatakan pendapat atas laporan keuangan yang diaudit.

\section{Audit Judgment}

Judgment menurut kamus Inggris-Indonesia diterjemahkan sebagai pendapat, keputusan, dan pertimbangan. Hogart (1992) mengartikan judgment sebagai proses kognitif yang merupakan perilaku pemilihan keputusan. Audit judgment merupakan kebijakan auditor dalam memberikan pendapat untuk menentukan hasil auditnya yang mengacu pada pembentukan suatu gagasan, pendapat atau perkiraan tentang suatu objek, peristiwa, status atau jenis peristiwa yang lain (Jamillah, 2007). Judgment seringkali dibutuhkan oleh auditor dalam melaksanakan audit suatu entitas terutama untuk menentukan hasil dari pelaksanaan audit.

Tanggung jawab besar seorang auditor yang sedang melaksanakan tugas audit terletak pada kemampuan mereka dalam membuat keputusan yang tepat berdasarkan judgment atas keterangan dan bukti-bukti. Seorang auditor akan mempertimbangkan dan juga memilih bukti audit mana yang nantinya akan digunakan, karena proses audit tidak dilakukan pada semua bukti yang ada. Auditor akan memilih bukti-bukti yang dicurigai terdapat kesalahan. Bukti-bukti inilah yang dijadikan sebagai pertimbangan bagi auditor untuk menyatakan pendapat atas hasil dari pelaksanaan auditnya. Oleh karena itu, jika auditor salah melakukan judgment maka hal ini tentunya berpengaruh terhadap laporan hasil auditnya. 


\section{Skeptisme}

Sikap skeptisme profesional merupakan salah satu sikap yang penting untuk digunakan oleh auditor dalam melakukan proses. Dimana sikap ini mencakup pikiran yang selalu mempertanyakan dan melakukan evaluasi secara kritis terhadap bukti audit. Bukti audit dikumpulkan dan dinilai selama proses audit. Skeptisme profesional auditor merupakan bagian yang tidak dapat dipisahkan dari proses audit.

Penelitian Gusti dan Ali (2008) memberikan bukti empiris bahwa skeptisme profesional auditor berpengaruh positif terhadap kualitas audit yang dihasilkan. Skeptisme profesional auditor dapat dipengaruhi oleh beberapa faktor. Hasil penelitian yang dilakukan oleh Prihandono (2012) memberikan hasil bahwa semakin tinggi tingkat skeptisme seorang auditor dalam melakukan audit, maka juga akan berpengaruh terhadap keputusan audit auditor tersebut. Berikutnya, penelitian Hartan (2016) menyatakan bahwa skeptisme profesional berpengaruh positif terhadap kemampuan auditor mendeteksi kecurangan, karena semakin tinggi tingkat skeptisme seorang auditor maka kemungkinan terjadinya kecurangan akan semakin kecil. Berdasarkan penelitian terdahulu maka, hipotesis yang diajukan adalah:

H1: Skeptisme berpengaruh positif terhadap audit judgement.

\section{Pengalaman Auditor}

Pengalaman merupakan suatu proses pembelajaran dan pertambahan potensi bertingkah laku baik dari pendidikan formal maupun non formal atau bisa diartikan sebagai suatu proses yang membawa seseorang pada suatu pola yang membawa seseorang kepada pola tingkah laku yang lebih tinggi. Pengalaman biasanya dikaitkan dengan keseringan atau intensitas melakukan sesuatu. Pengalaman erat kaitannya dengan keahlian auditor.

Seseorang yang berpengalaman dapat mengerjakan sesuatu dengan cepat dan benar karena dia sudah sering melakukan hal tersebut. Audit judgment yang dibuat oleh auditor yang berpengalaman jauh/bisa lebih baik dibandingkan dengan audit judgment yang dibuat oleh auditor yang tidak/belum berpengalaman. Banyaknya pengalaman dalam bidang audit dapat membantu auditor dalam menyelesaikan tugas yang cenderung memiliki pola yang sama (Ariyantini dkk, 2014). Penelitian Januarti dan Shabrina (2011) menyatakan pengalaman berpengaruh positif terhadap audit judgment karena semakin banyak penugasan audit yang dialami auditor maka akan semakin baik pula judgment yang akan dibuat. Penelitian Praditaningrum (2012) menghasilkan hasil penelitian bahwa auditor yang berpengalaman dapat mengambil pertimbangan yang baik dan berkualitas. Demikian pula hasil penelitian Praditaningrum didukung oleh penelitian Lestari (2015). Berdasarkan uraian diatas maka, dirumuskan hipotesis sebagai berikut :

H2 : Pengalaman auditor berpengaruh positif terhadap audit judgment.

\section{Self- Efficacy}

Self-Efficacy atau efikasi diri yang merupakan persepsi/keyakinan kemampuan diri sendiri. Ketika seseorang memiliki self-efficacy yang tinggi, maka ia akan mampu memotivasi dirinya untuk melakukan pekerjaannya dengan sebaik mungkin, khususnya bagi seorang auditor, kinerja seorang auditor akan sangat berpengaruh terhadap setiap pertimbangan keputusan yang dibuatnya. Dengan adanya self-efficacy, maka sebelum membuat audit judgment auditor akan termotivasi untuk mengumpulkan segala bukti yang kuat terlebih dahulu dan ia akan memfokuskan dirinya untuk menganalisa setiap bukti pendukung dalam pekerjaannya sehingga setiap judgment yang dibuat akan lebih tepat (Iskandar dan Sanusi, 2011) 
Menurut penelitian yang dilakukan oleh Iskandar dan Sanusi (2011) menemukan hasil bahwa, seseorang yang memiliki tingkat self-efficacy yang tinggi akan memberikan hasil yang lebih baik pada audit judgment dibandingkan dengan seseorang yang memiliki tingkat selfefficacy yang rendah pada tugas yang sederhana. Penelitian Wijayantini (2014) juga memberikan hasil bahwa self efficacy berpengaruh positif terhadap audit judgment, karena semakin tinggi self efficacy yang dimiliki auditor maka akan semakin baik pula judgment yang akan dikeluarkan nantinya oleh auditor. Selanjutnya, penelitian Lestari (2015) juga membuktikan bahwa semakin tinggi self efficacy yang dimiliki seseorang maka audit judgment yang dihasilkan juga semakin baik. Sehingga dirumuskan hipotesis sebagai berikut :

H3: Self-efficacy berpengaruh positif terhadap audit judgment.

\section{METODE PENELITIAN}

\section{Populasi dan Sampel}

Populasi merupakan keseluruhan kelompok orang, kejadian atau hal minat yang ingin peneliti investigasi (Sekaran, 2006). Populasi yang digunakan dalam penelitian ini adalah seluruh auditor internal pemerintah yang bekerja pada Kantor Badan Pengawas Keuangan dan Pembangunan (BPKP) Perwakilan Provinsi Bengkulu.

Sampel merupakan subkelompok atau bagian dari populasi (Sekaran, 2006). Sampel pada penelitian ini adalah para auditor pemerintah yang bekerja di kantor BPKP Perwakilan Provinsi Bengkulu yang berjumlah 60 orang. Pada penelitian ini, peneliti mengumpulkan data dari responden melalui kuisioner yang dibagikan kepada responden. Metode yang digunakan dalam penentuan sampel penelitian ini adalah purposive sampling secara tidak acak yang informasinya diperoleh dengan menggunakan pertimbangan tertentu (umumnya disesuaikan dengan tujuan atau masalah penelitian) (Indriantoro dan Supomo, 2002). Kriteria sampel penelitian adalah auditor yang langsung ikut terlibat dalam pemeriksaan dilapangan dan auditor yang telah bekerja minimal 2 tahun dalam bidang audit.

\section{Metode Pengumpulan Data}

Metode pengumpulan data yang dilakukan dalam penelitian ini adalah data primer berupa kuesioner. Kuesioner ialah satu set pertanyaan yang telah dirumuskan untuk mencatat jawaban dari para responden (Sekaran, 2006). Data penelitian ini dilakukan dengan cara mengantarkan langsung kuesioner ke alamat kantor tempat auditor bekerja yaitu BPKP Perwakilan Provinsi Bengkulu. Data primer diperoleh dengan menggunakan daftar pertanyaan yang dibuat secara terstruktur dengan tujuan untuk mengumpulkan informasi dari auditor yang bekerja di BPKP Perwakilan Provinsi Bengkulu sebagai responden dalam penelitian. Pertanyaan kuisioner merupakan pertanyaan tertutup dan terdiri dari dua bagian. Bagian pertama mengenai deskriptif responden secara demografi dan bagian kedua berupa pertanyaan untuk mendapatkan informasi tentang skeptisme, pengalaman auditor, self-efficacy dan audit judgment. Petunjuk pengisian kuesioner dibuat dengan sesederhana dan sejelas mungkin agar mempermudah responden dalam pengisian kuesioner.

\section{Variabel Dependen}

Variabel dependen adalah variabel terikat yang dalam penelitian ini adalah Audit Judgment. Audit Judgment dalam penelitian ini merupakan kebijakan auditor untuk menentukan 
hasil auditnya sesuai dengan pertimbangan yang dimiliki. Instrumen audit judgment terdiri dari lima item pertanyaan yang mana masing-masing pertanyaan diukur dengan menggunakan skala likert lima poin yaitu $1=$ sangat tidak setuju, $2=$ tidak setuju, $3=$ netral, $4=$ setuju, dan $5=$ sangat setuju.

\section{Variabel Independen \\ Skeptisme (SK)}

Skeptisme profesional auditor merupakan sikap (attitude) auditor dalam melakukan penugasan audit dimana sikap ini mencakup pikiran yang selalu mempertanyakan dan melakukan evaluasi secara kritis terhadap bukti audit. Instrumen skeptisme terdiri dari delapan item pertanyaan yang mana masing-masing pertanyaan diukur dengan menggunakan skala likert lima poin yaitu 1 = sangat tidak setuju, $2=$ tidak setuju, $3=$ netral, $4=$ setuju, dan $5=$ sangat setuju.

\section{Pengalaman Auditor (PA)}

Pengalaman merupakan suatu proses pembelajaran dan pertambahan potensi bertingkah laku baik dari pendidikan formal maupun non formal atau bisa diartikan sebagai suatu proses yang membawa seseorang pada suatu pola tingkah laku yang lebih tinggi. Instrumen pengalaman auditor terdiri dari enam item pertanyaan yang mana masing-masing pertanyaan diukur dengan menggunakan skala likert lima poin yaitu $1=$ sangat tidak setuju, $2=$ tidak setuju, $3=$ netral, $4=$ setuju, dan 5 = sangat setuju.

\section{Self-Efficacy (SE)}

Bandura (2006) menyatakan bahwa self efficacy adalah kepercayaan seseorang bahwa dia dapat menjalankan sebuah tugas pada sebuah tingkat tertentu, yang mempengaruhi aktivitas pribadi termasuk dalam kegiatan pengambilan keputusan yaitu audit judgment seorang auditor. Instrumen self-efficacy terdiri dari tujuh item pertanyaan yang mana masing-masing pertanyaan diukur dengan menggunakan skala likert lima poin yaitu $1=$ sangat tidak setuju, $2=$ tidak setuju, $3=$ netral, $4=$ setuju, dan $5=$ sangat setuju.

\section{Metode Analisis Data}

Analisis data dilakukan dengan bantuan program computer yaitu SPSS (Statistical Package For Social Science) versi 17.0.

\section{Uji Statistik Deskriptif}

Statistik deskriptif ini digunakan untuk memberikan informasi mengenai karakteristik masing-masing variabel yang ada dalam penelitian dan daftar demografi para responden. Menurut Ghozali (2013) statistik deskriptif memberikan gambaran atau deskripsi suatu data yang dilihat dari nilai rata-rata (mean), standar deviasi, varian, maksimum, minimum.

\section{Uji Validitas}

Uji validitas digunakan untuk mengukur sah atau valid tidaknya suatu kuisioner. Pengujian ini menggunakan metode Confirmatory factor analysis (CFA) untuk mengukur tingkat interkorelasi antar variabel dan dapat tidaknya dilakukan analisis faktor adalah Kaiser-MeyerOlkin Measure of Sampling Adequecy (KMO MSA). 
PENGARUH SKEPTISME, PENGALAMAN AUDITOR DAN SELF EFFICACY TERHADAP

Wiwien Maryani dan Fitrawati Ilyas

\section{Uji Reliabilitas}

Menurut Ghozali (2013) Reliabilitas sebenarnya adalah alat untuk mengukur suatu kuesioner yang merupakan indikator dari variabel atau konstruk. Reliabilitas diukur dengan uji statistik Cronbach Alpha. Suatu konstruk atau variabel dikatakan reliabel jika nilai Cronbach Alpha $>0,7$.

\section{Uji Asumsi Klasik}

Penelitian ini menggunakan regresi berganda untuk menguji hipotesis. Oleh karena itu, diperlukan uji asumsi klasik. Uji asumsi klasik terdiri dari : Uji normalitas, uji multikolinearitas, uji heteroskedasitisitas yang dilakukan dengan bantuan software SPSS.

\section{HASIL DAN PEMBAHASAN}

\section{Tingkat Pengembalian Kuesioner}

Penelitian ini dilaksanakan pada kantor BPKP Perwakilan Provinsi Bengkulu. Data penelitian ini dikumpulkan dengan menyebarkan kuesioner kepada auditor Kantor Badan Pengawas Keuangan dan Pembangunan (BPKP) yang menjadi responden penelitian ini. Penelitian ini dilakukan sejak tanggal 6 Februari 2017 sampai dengan 28 Februari 2017. Jumlah kusioner yang disebarkan sebanyak 60 kuesioner. Kuesioner didistribusikan kesemua jajaran fungsional auditor yang bekerja di kantor BPKP Perwakilan Provinsi Bengkulu. Secara lebih rinci jumlah kuesioner yang tingkat pengembalian kuesioner dapat dilihat pada tabel 1

\section{Tabel 1}

Tingkat Pengembalian Kuesioner

\begin{tabular}{l|c|c}
\hline \multicolumn{1}{c|}{ Keterangan } & Jumlah & Persentase (\%) \\
\hline Kuesioner yang didistribusikan & 60 & $100 \%$ \\
\hline Kuesioner yang kembali & 60 & $100 \%$ \\
\hline Kuesioner yang gugur & 8 & $13,3 \%$ \\
\hline Kuesioner yang bisa diolah & 52 & $86,7 \%$ \\
\hline
\end{tabular}

Sumber : Data Primer yang diolah, 2017

Dari tabel 1 diatas dapat dilihat bahwa 60 kuesioner yang disebarkan kepada responden dan semuanya kembali, namun ada 8 yang tidak diisi dengan lengkap, sehingga kuisioner yang bisa diolah sebanyak 52 kuesioner atau sebesar $86,7 \%$.

\section{Profil Responden}

Berdasarkan 52 kuesioner yang dapat diolah, diperoleh informasi mengenai demografi responden sebagai acuan dalam melihat karakteristik responden yang menjadi sampel penelitian. Secara lebih rinci demografi responden dapat dilihat pada tabel 2 berikut :

Tabel 2

Profil Responden

\begin{tabular}{|c|c|c|}
\hline Profil Responden & $\mathrm{Jlh}$ & $\%$ \\
\hline Jenis Kelamin: & & \\
\hline 1. Pria & 34 & $65,4 \%$ \\
\hline
\end{tabular}




\begin{tabular}{|c|c|c|}
\hline Wanita & 18 & $34,6 \%$ \\
\hline Jumlah & 52 & $100 \%$ \\
\hline \multicolumn{3}{|l|}{ Usia Responden: } \\
\hline$\leq 25$ & 5 & $9,6 \%$ \\
\hline $26-35$ & 27 & $51,9 \%$ \\
\hline $36-45$ & 14 & $26,9 \%$ \\
\hline$>45$ & 6 & $11,5 \%$ \\
\hline Jumlah & 52 & $100 \%$ \\
\hline \multicolumn{3}{|l|}{ Pendidikan Terakhir: } \\
\hline D3 & 6 & $11,5 \%$ \\
\hline S1 & 44 & $84,6 \%$ \\
\hline S2 & 2 & $3,8 \%$ \\
\hline Jumlah & 52 & $100 \%$ \\
\hline \multicolumn{3}{|l|}{ Pengalaman Kerja: } \\
\hline 2-4Tahun & 11 & $21,1 \%$ \\
\hline$>4-6$ Tahun & 17 & $32,7 \%$ \\
\hline$>6$ Tahun & 24 & $46,2 \%$ \\
\hline Jumlah & 52 & $100 \%$ \\
\hline Jabatan Auditor: & & \\
\hline $\begin{array}{l}\text { 1. Auditor Pelaksana } \\
\text { 2. Auditor Pelaksana }\end{array}$ & 4 & $7,7 \%$ \\
\hline Lanjutan & 5 & $9,6 \%$ \\
\hline 3. Auditor Penyelia & 7 & $13,5 \%$ \\
\hline 4. Auditor Pertama & 19 & $36,5 \%$ \\
\hline 5. Auditor Muda & 9 & $17,3 \%$ \\
\hline 6. Auditor Madya & 6 & $11,5 \%$ \\
\hline 7. Auditor Utama & 2 & $3,8 \%$ \\
\hline Jumlah & 52 & $100 \%$ \\
\hline
\end{tabular}

Dari 52 kuesioner yang diolah, gambaran umum mengenai responden yang terinci dapat dilihat pada tabel 4.2. Dilihat dari jenis kelamin para responden laki-laki berjumlah 34 orang dan wanita berjumlah 18 orang, artinya bahwa jumlah responden pria mendominasi yaitu sebesar $65,4 \%$ dibanding jumlah responden wanita yaitu sebesar 34,6\%. Berdasarkan kelompok usia responden didominasi oleh responden yang berusia 26-35 tahun yakni sebanyak 27 orang atau sebesar $51,9 \%$. Selanjutnya responden yang berusia 36-45 tahun adalah sebayak 14 orang atau sebesar $26,9 \%$ dan $>45$ tahun sebanyak 6 orang atau sebesar $11,5 \%$.

Berdasarkan tingkat pendidikan yang ditempuh, sebagian besar responden memiliki tingkat pendidikan S1 dengan persentase 84,6\% ( sebanyak 44 orang), sedangkan D3 dengan persentase $11,5 \%$ (6 orang) dan S2 dengan persentase 3,8 \% (2 orang). Apabila dilihat dari pengalaman bekerja, responden yang mendominasi adalah responden yang bekerja $>6$ tahun sebanyak 24 orang atau sebesar 46,2\%, kemudian diikuti oleh responden yang bekerja >4-6 tahun sebanyak 17 orang atau sebesar 32,7\% dan yang bekerja selama 2-4 tahun adalah sebanyak 11 orang atau sebesar $21,1 \%$. 
Dilihat berdasarkan jabatannya, yang menjabat sebagai auditor pelaksana sebanyak 4 orang $(7,7 \%)$, yang menjabat sebagai auditor pelaksana lanjutan sebanyak 5 orang $(9,6 \%)$, yang menjawab sebagai auditor penyelia sebanyak 7 orang $(13,5 \%)$, yang menjabat sebagai auditor pertama sebanyak 19 orang $(36,5 \%)$, yang menjabat sebagai auditor muda sebanyak 9 orang $(17,3 \%)$, yang menjabat sebagai auditor madya 6 orang $(11,5 \%)$, dan yang menjabat sebagai auditor utama adalah sebanyak 2 orang $(3,8 \% \%)$.

\section{Statistik Deskriptif}

Semua kuesioner yang sudah terkumpul ditabulasi untuk tujuan analisis data. Hasil tabulasi diolah dengan menggunakan program SPSS 17 yang menghasilkan statistik deskriptif variabel penelitian seperti yang tampak pada tabel 3 .

Tabel 3

Statistik Deskriptif

\begin{tabular}{c|c|c|c|c|c|c}
\hline Variabel & $\mathrm{N}$ & $\begin{array}{c}\text { Kisaran } \\
\text { Teoritis }\end{array}$ & $\begin{array}{c}\text { Kisaran } \\
\text { Aktual }\end{array}$ & $\begin{array}{c}\text { Rata-rata } \\
\text { Teoritis }\end{array}$ & $\begin{array}{c}\text { Rata-rata } \\
\text { Aktual }\end{array}$ & $\begin{array}{c}\text { Standar } \\
\text { Deviasi }\end{array}$ \\
\hline Skeptisme & 52 & $8-40$ & $30-40$ & 24 & 34,40 & 2,584 \\
\hline $\begin{array}{c}\text { Pengalaman } \\
\text { Auditor }\end{array}$ & 52 & $6-30$ & $22-30$ & 18 & 25,88 & 2,184 \\
\hline Self Efficacy & 52 & $7-35$ & $22-35$ & 21 & 29,23 & 3,104 \\
\hline Audit Judgment & 52 & $5-25$ & $19-25$ & 15 & 22,06 & 1,798 \\
\hline
\end{tabular}

Sumber: Data diolah 2017

Berdasarkan statistik deskriptif yang telah dijabarkan dalam Tabel 4.3.Variabel Skeptisme memiliki nilai rata-rata teoritis sebesar 24 , sedangkan untuk nilai rata-rata aktualnya sebesar 34,40. Nilai rata-rata kisaran aktual yang lebih besar dari teoritis mengindikasikan bahwa ratarata jawaban responden terhadap variabel skeptisme menyatakan bahwa sifat skeptisme pada auditor BPKP sudah baik. Standar deviasi sebesar 2,584 yang lebih kecil dibandingkan dengan nilai rata-rata menunjukkan bahwa jawaban responden tidak ada variasi data pada variabel skeptisme.

Variabel pengalaman auditor memiliki nilai rata-rata teoritis sebesar 18, sedangkan untuk nilai rata-rata aktualnya sebesar 25,88 . Nilai rata-rata kisaran aktual yang lebih besar dari teoritis mengindikasikan bahwa rata-rata jawaban responden terhadap variabel pengalaman auditor sangat baik. Standar deviasi sebesar 2,184 yang lebih kecil dibandingkan dengan nilai rata-rata menunjukkan bahwa jawaban responden tidak ada variasi data pada variabel pengalaman auditor.

Variabel self efficacy memiliki nilai rata-rata teoritis sebesar 21, sedangkan untuk nilai rata-rata aktualnya sebesar 29,23 . Nilai rata-rata kisaran aktual yang lebih besar dari teoritis mengindikasikan bahwa rata-rata jawaban responden terhadap variabel self efficacy menyatakan bahwa self efficacy pada auditor BPKP yang tinggi. Standar deviasi sebesar 3,104 yang lebih kecil dibandingkan dengan nilai rata-rata menunjukkan bahwa jawaban responden tidak ada variasi data pada variabel self efficacy.

Variabel audit judgment memiliki nilai rata-rata teoritis sebesar 15, sedangkan untuk nilai rata-rata aktualnya sebesar 22,06. Nilai rata-rata kisaran aktual yang lebih besar dari teoritis mengindikasikan bahwa rata-rata jawaban responden terhadap variabel audit judgment menyatakan bahwa audit judgment yang dibuat oleh auditor BPKP sudah baik. Standar deviasi 
sebesar 1,730 yang lebih kecil dibandingkan dengan nilai rata-rata menunjukkan bahwa jawaban responden tidak ada variasi data pada variabel audit judgment.

\section{Hasil Uji Validitas}

Pengujian ini menggunakan metode (confirmatory factor analysis) CFA dimana nilai KMO (Kaiser-Meyer-Olkin) dari analisis menunjukkan nilai > 0,05 dan nilai MSA (measure of sampling adequacy) > 0,50, maka indikator pertanyaan atau data dikatakan valid. Hasil pengujian validitas dapat dilihat pada tabel dibawah ini:

\section{Tabel4}

Hasil Uji Validitas Data

\begin{tabular}{|c|c|c|c|c|}
\hline Variabel Penelitian & Item & Nilai KMO & Nilai MSA & Ket \\
\hline \multirow[t]{8}{*}{ Skeptisme } & SK1 & \multirow[t]{8}{*}{0,745} & 0,641 & Valid \\
\hline & SK2 & & 0,803 & Valid \\
\hline & SK3 & & 0,722 & Valid \\
\hline & SK4 & & 0,765 & Valid \\
\hline & SK5 & & 0,798 & Valid \\
\hline & SK6 & & 0,798 & Valid \\
\hline & SK7 & & 0,703 & Valid \\
\hline & SK8 & & 0,576 & Valid \\
\hline \multirow[t]{6}{*}{ Pengalaman Auditor } & PA1 & \multirow[t]{6}{*}{0,752} & 0,786 & Valid \\
\hline & PA2 & & 0,730 & Valid \\
\hline & PA3 & & 0,783 & Valid \\
\hline & PA4 & & 0,757 & Valid \\
\hline & PA5 & & 0,824 & Valid \\
\hline & PA6 & & 0,604 & Valid \\
\hline \multirow[t]{7}{*}{ Self Efficacy } & SE1 & \multirow[t]{7}{*}{0,871} & 0,740 & Valid \\
\hline & SE2 & & 0,832 & Valid \\
\hline & SE3 & & 0,829 & Valid \\
\hline & SE4 & & 0,785 & Valid \\
\hline & SE5 & & 0,762 & Valid \\
\hline & SE6 & & 0,696 & Valid \\
\hline & SE7 & & 0,616 & Valid \\
\hline \multirow[t]{5}{*}{ Audit Judgment } & AJ1 & \multirow[t]{5}{*}{0,781} & 0,805 & Valid \\
\hline & $\mathrm{AJ} 2$ & & 0,791 & Valid \\
\hline & $\mathrm{AJ} 3$ & & 0,756 & Valid \\
\hline & $\mathrm{AJ} 4$ & & 0,782 & Valid \\
\hline & AJ5 & & 0,776 & Valid \\
\hline
\end{tabular}

Sumber: Data diolah 2017 
PENGARUH SKEPTISME, PENGALAMAN AUDITOR DAN SELF EFFICACY TERHADAP

Wiwien Maryani dan Fitrawati Ilyas

Dari tabel diatas dapat disimpulkan bahwa pertanyaan-pertanyaan dari variabel-variabel memiliki nilai KMO dan MSA > 0,5. Artinya semua pertanyaan-pertanyaan yang digunakan untuk mengukur variabel-variabel tersebut dapat dikatakan sudah valid.

\section{Hasil Uji Reliabilitas}

Uji Reliabilitas data diukur dengan uji statistik Cronbach Alpha dimana suatu konstruk atau variabel dikatakan reliabel jika nilai Cronbach Alpha >0,7. Hasil pengujian Reliabilitas data dapat dilihat pada tabel berikut ini:

Tabel 5

Hasil Uji Reliabilitas

\begin{tabular}{l|c|c}
\hline \multicolumn{1}{c|}{ Variabel } & Cronbach's alpha & Ket \\
\hline Skeptisme & 0,718 & Reliabel \\
\hline Pengalaman Auditor & 0,722 & Reliabel \\
\hline Self Efficacy & 0,858 & Reliabel \\
\hline Audit Judgment & 0,741 & Reliabel \\
\hline
\end{tabular}

Sumber: Data diolah 2017

Dari tabel diatas dapat disimpulkan bahwa pertanyaan-pertanyaan dari variabel-variabel nilai Cronbach's Alpha > 0,7. Artinya semua pertanyaan-pertanyaan yang digunakan untuk mengukur variabel-variabel tersebut adalah reliabel.

\section{Uji Normalitas}

Uji normalitas digunakan untuk menguji apakah dalam sebuah model regresi, variabel dependen dan variabel independen atau keduanya mempunyai distribusi normal atau tidak. Model regresi yang baik adalah distribusi data normal atau mendekati normal. Uji normalitas data dalam penelitian ini menggunakan Uji Kolmogorov-Smirnov (Uji K-S) dengan ringkasan hasil analisis sebagaimana disajikan pada tabel 6.

\section{Tabel 6}

\section{Hasil Uji Normalitas}

\begin{tabular}{l|l|l|l}
\hline Variabel & $\begin{array}{l}\text { Kolmogorov- } \\
\text { Smirnov Z }\end{array}$ & $\begin{array}{l}\text { Asymp. Sign } \\
\text { (tailed) }\end{array}$ & Keterangan \\
\hline Unstandardized Residual & 0,784 & 0,570 & Normal \\
\hline Sumber
\end{tabular}

Sumber : Data Primer diolah, 2017

Tabel 6 menunjukkan nilai KS sebesar 0,784, jika nilai signifikan dari pengujian one sample kolmologorov-smirnov test $>0.05$ maka data mempunyai distribusi normal. Nilai KS yang didapatkan 0,784 yang berarti lebih besar dari 0,05, jadi dapat disimpulkan bahwa model regresi ini telah memenuhi asumsi normalitas.

\section{Hasil Uji Multikolonieritas}

Uji multikoleniaritas bertujuan untuk menguji apakah dalam model regresi ditemukan adanya korelasi antara variabel bebas (independen). Model regresi yang baik seharusnya tidak terjadi korelasi diantara variabel independen. Hal tersebut dapat dilihat apabila nilai tolerance 
lebih besar dari 10\% atau VIF kurang dari 10, apabila syarat tersebut terpenuhi maka dikatakan bahwa dalam model regresi tidak ada multikoleniaritas. Hasil uji multikolinearitas dapat dilihat pada tabel 7.

Tabel 7

Hasil Uji Multikolinearitas

\begin{tabular}{l|c|c|c}
\hline \multirow{2}{*}{ Variabel Independen } & Colinearity Statistic & Ket & \multirow{2}{*}{ Ket } \\
\cline { 2 - 3 } & Tolerance & VIF & \\
\hline Skeptisme & 0,774 & 1,292 & Tidak ada multikolinearitas \\
\hline Pengalaman Auditor & 0,736 & 1,370 & Tidak ada multikolinearitas \\
\hline Self Efficacy & 0,935 & 1,070 & Tidak ada multikolinearitas \\
\hline
\end{tabular}

Sumber : Data Primer diolah, 2017

Berdasarkan Tabel 7 di atas terlihat bahwa nilai tolerance variabel independen Skeptisme, pengalaman auditor, dan self efficacy mempunyai tolerance lebih dari 0,10 yang berarti bahwa tidak ada korelasi antar vaiabel independen. Sementara hasil perhitungan VIF (Variance Inflation Factor) juga menunjukkan hal yang sama, tidak ada satupun variabel independen yang memiliki VIF kurang dari 10. Dengan demikian dapat disimpulkan tidak terjadi multikolinearitas antar variabel bebas.

\section{Hasil Uji Heteroskedastisitas}

Pengujian heteroskedastisitas dilakukan untuk menguji apakah dalam sebuah model regresi terjadi ketidaksamaan varians residual dari satu pengamatan ke pengamatan yang lain. Jika varians dari residual suatu pengamatan ke pengamatan yang lain tetap, maka disebut homoskedastisitas. Pengujian ini dilakukan dengan Uji Glejser. Jika signifikansi t dari hasil meregresi nilai absolute residual terhadap variabel bebas lebih dari 0,05 maka model regresi tidak mengandung heteroskedastisitas.

Tabel 8

Hasil Uji Glejser

\begin{tabular}{l|c|l}
\hline \multicolumn{1}{c|}{ Variabel } & Sign. & \multicolumn{1}{c}{ Keterangan } \\
\hline Skeptisme & 0,504 & Tidak mengandung heteroskedastisitas \\
\hline Pengalaman Auditor & 0,955 & Tidak mengandung heteroskedastisitas \\
\hline Self Efficacy & 0,407 & Tidak mengandung heteroskedastisitas \\
\hline
\end{tabular}

Sumber : Data Primer diolah, 2017

Berdasarkan Tabel 8 menunjukkan bahwa nilai signifikansi masing-masing variabel bebas lebih dari 0,05 (5\%), Hal ini berarti tidak terjadi heteroskedastisitas pada model persamaan regresi, sehingga model regresi layak digunakan untuk memprediksi audit judgment berdasarkan variabel yang mempengaruhinya, yaitu skeptisme, pengalaman auditor, dan self-efficacy.

\section{Hasil Pengujian Hipotesis}

Setelah hasil uji asumsi klasik dilakukan dan hasilnya secara keseluruhan menunjukkan model regresi memenuhi asumsi klasik, maka tahap berikutnya adalah melakukan evaluasi dan interprestasi model regresi berganda. Model regresi berganda penelitian ini adalah untuk menguji skeptisme, pengalaman auditor dan self efficacy (variabel independen) berpengaruh terhadap 
PENGARUH SKEPTISME, PENGALAMAN AUDITOR DAN SELF EFFICACY TERHADAP

Wiwien Maryani dan Fitrawati Ilyas

audit judgment (variabel dependen). Hasil olahan data yang diolah menggunakan program SPSS 17 dapat dilihat pada tabel 9

Tabel 9

Hasil Uji Regresi Linear Berganda

\begin{tabular}{l|c|c|c}
\hline \multicolumn{1}{c|}{ Variabel } & Koef Regresi & T Hitung & Sign \\
\hline Skeptisme & 0,278 & 2,128 & 0,039 \\
\hline Pengalaman Auditor & 0,276 & 2,049 & 0,046 \\
\hline Self Efficacy & 0,291 & 2,442 & 0,018 \\
\hline R Square & & 0,365 \\
\hline Adjusted R Square & 0,325 \\
\hline F & 9,197 \\
\hline Sign & & 0,000 \\
\hline
\end{tabular}

Sumber : Data Primer diolah, 2017

\section{Hasil Uji Regresi Model (Uji F)}

Uji $\mathrm{F}$ digunakan untuk menguji kelayakan model yang digunakan dalam persamaan regresi berganda (goodness of fit model). Berdasarkan hasil regresi pada tabel 4.9 dapat dilihat bahwa nilai statistik $\mathrm{F}$ dalam model adalah sebesar 9,197 dengan nilai signifikansi 0,000. Nilai probabilitas 0,000 lebih kecil dari 0,05 menunjukkan bahwa model yang digunakan dalam penelitian layak untuk digunakan.

\section{Hasil Uji Determinasi}

Uji koefisien determinasi dilakukan untuk mengukur kemampuan variabel independen, yaitu skeptisme, pengalaman auditor, dan self-efficacy dalam menjelaskan variabel dependen yaitu audit judgment. Berdasarkan tabel 4.9 juga dapat dilihat nilai Adjusted $R$ square model pertama sebesar 0,325 yang menunjukkan bahwa 32,5\% variabel audit judgment dapat dijelaskan oleh variabel skeptisme, pengalaman auditor dan self efficacy sedangkan sisanya dijelaskan oleh variabel lain yang tidak terdapat dalam persamaan ini.

\section{Hasil Pengujian Hipotesi 1}

Dari tabel 9 diketahui bahwa nilai t-hitung variabel skeptisme sebesar 2,128 dengan probabilitas (sigifikansi) sebesar $0,039<0,05$. Hasil tersebut meyimpulkan bahwa skeptisme berpengaruh positif terhadap audit judgment. Dengan demikian disimpulkan bahwa hipotesis pertama (H1) diterima.

\section{Hasil Pengujian Hipotesis 2}

Dari tabel 9 diketahui bahwa nilai t-hitung variabel pengalaman auditor sebesar 2,049 dengan probabilitas (sigifikansi) sebesar $0.046<0,05$. Hasil tersebut meyimpulkan bahwa pengalaman auditor berpengaruh positif terhadap audit judgment. Dengan demikian disimpulkan bahwa hipotesis kedua (H2) diterima. 


\section{Hasil Pengujian Hipotesis 3}

Dari tabel 9 diketahui bahwa nilai t-hitung variabel self efficacy sebesar 2,442 dengan probabilitas (sigifikansi) sebesar $0.018<0,05$. Hasil tersebut meyimpulkan bahwa self efficacy berpengaruh positif terhadap audit judgment. Dengan demikian disimpulkan bahwa hipotesis ketiga $(\mathrm{H} 3)$ diterima.

\section{HASIL DAN PEMBAHASAN}

Hasil penelitian hipotesis pertama (H1) diterima, artinya skeptisme berpengaruh positif terhadap audit judgment. Hal ini menunjukkan bahwa semakin skeptisme seorang auditor dalam melaksanakan penugasan audit maka akan semakin baik pula audit judgment yang dihasilkan. Hasil penelitian yang membuktikan skeptisme berpengaruh terhadap audit judgment mendukung beberapa penelitian terdahulu yang dilakukan oleh Gusti dan Ali (2008) dan juga yang dilakukan oleh Prihandono (2012) yang memberikan hasil bahwa semakin tinggi tingkat skeptisme seseorang maka akan semakin meningkatkan audit judgment dan meningkatkan kualitas audit dan penelitian Hartan (2016) yang menyatakan semakin tinggai tingkat skeptisme akan meningkatkan kemampuan auditor mendeteksi kecurangan, karena semakin tinggi tingkat skeptisme seorang auditor maka kemungkinan terjadinya kecurangan akan semakin kecil.

Hasil penelitian hipotesis kedua (H2) diterima, artinya pengalaman auditor berpengaruh positif terhadap audit judgment. Hal ini menunjukkan bahwa semakin banyak pengalaman seorang auditor dalam melaksanakan tugas audit maka akan semakin baik pula audit judgment yang dihasilkan. Hasil penelitian ini berhasil mendukung beberapa penelitian terdahulu yang menyatakan bahwa pengalaman auditor berpengaruh positif terhadap audit judgment yang pernah dilakukan oleh Januarti dan Shabrina (2011) menyatakan semakin banyak penugasan audit yang dilakukan auditor maka akan semakin baik pula judgment yang akan dibuat. Penelitian Praditaningrum (2012) menghasilkan hasil penelitian bahwa auditor yang berpengalaman dapat mengambil pertimbangan yang baik dan berkualitas. Demikian pula hasil penelitian ini mendukung penelitian Lestari (2015) yang berkesimpulan bahwa auditor yang berpengalaman dan ahli dapat mengambil audit judgment yang relatif lebih baik dan berkualitas.

Hasil penelitian hipotesis ketiga (H3) diterima, artinya self efficacy berpengaruh positif terhadap audit judgment. Hal ini menunjukkan bahwa semakin tinggi self efficacy auditor dalam melaksanakan tugas audit maka akan meningkatkan audit judgment yang dihasilkan. Adanya self efficacy atau keyakinan diri yang tinggi dikarenakan banyaknya pengalaman yang telah dilalui auditor dalam mengaudit, sehingga apapun tugas yang diberikan maka ia dapat menyelesaikan pekerjaannya dengan sebaik mungkin. Hasil penelitian ini mendukung beberapa penelitian terdahulu yang dilakukan oleh Iskandar dan Sanusi (2011) yang menyatakan bahwa self efficacy berpengaruh positif terhadap audit judgment dan sejalan dengan penelitian Wijayantini (2014) juga memberikan hasil bahwa self efficacy berpengaruh positif terhadap audit judgment, karena semakin tinggi self efficacy yang dimiliki auditor maka akan semakin baik pula judgment yang akan dikeluarkan nantinya oleh auditor. Selanjutnya, penelitian Lestari (2015) juga membuktikan bahwa semakin tinggi self efficacy yang dimiliki seseorang maka audit judgment yang dihasilkan juga semakin baik. 


\section{PENUTUP}

\section{Simpulan}

Berdasarkan hasil penelitian dapat diambil kesimpulan sebagai berikut:

1. Skeptisme terbukti berpengaruh positif terhadap audit judgment. Hal ini berarti sikap skeptisme seorang auditor terbukti dapat meningkatkan kualitas dari audit judgment yang diambil seorang auditor.

2. Pengalaman auditor terbukti berpengaruh positif terhadap audit judgment. Hal ini berarti pengalaman auditor terbukti dapat meningkatkan kualitas dari audit judgment yang dihasilkan seorang auditor.

3. Self efficacy terbukti berpengaruh positif terhadap audit judgment. Hal ini berarti self efficacy terbukti dapat meningkatkan audit judgment auditor seorang auditor.

Berdasarkan pembahasan dan kesimpulan diatas, maka peneliti menyarankan bahwa:

1. Penelitian selanjutnya hendaknya tidak hanya menggunakan kuesioner dalam mengumpulkan data, tetapi disertai dengan wawancara secara langsung terhadap responden.

2. Penelitian ini masih terbatas pada skeptisme, pengalaman auditor dan self efficacy. Untuk penelitian selanjutnya dapat menambahkan variabel-variabel lain yang dapat mempengaruhi audit judgment seperti independensi, kompleksitas tugas, dan keahlian.dll.

3. Peneliti selanjutnya hendaknya dapat memperluas objek penelitian dengan melibatkan auditor pemerintah lainnya seperti auditor inspektorat dan auditor dari sektor privat (swasta) sehingga dapat dijadikan generalisasi secara keseluruhan.

\section{DAFTAR PUSTAKA}

Abdul Halim. (2003). Auditing 1 Dasar-dasar Audit Laporan Keuangan. Edisi 2.Unit Penerbit dan Percetakan AMP YKPN.

Arifuddin, Faridah, Yusi, W. 2002. Hubungan antara Judgment Audit dengan Risiko dan Materialitas. Jurnal Bisnis dan Akuntansi STIE Trisakti. Hal 102 - 117.

Ariyantini, Kadek Evi. Sujana, Edi. Darmawan Nyoman Ari Surya. 2014. Pengaruh Pengalaman Auditor, tekanan ketaatan dan kompleksitas tugas terhadap audit judgment (studi empiris pada BPKP perwakilan provinsi Bali. e-journal S1 Ak Universitas Pendidikan Ganesha. Volume 2 No 1.Hal 1-10

Apsah, Siti. 2012. Pengaruh Kompleksitas Tugas, Job Stress, dan Self efficacy terhadap Kinerja Auditor dalam Pembuatan Audit Judgment. Skripsi Fakultas Ekonomi Universitas Islam Negeri Syarif Hidayatullah Jakarta.

Bandura, Albert. 2006. Self Efficacy The Exercise of Control. New York. W. H. Freeman and Company.

Beck, R. C. 1990. Motivation. Englewood Cliffs, N J. : Prentice Hall.

Boynton, William C., Johnson, Raymond N., Kell, Walter G. 2001. Modern Auditing. Edisi Ketujuh. Jilid I. Penerbit Erlangga, Jakarta.

Ananing, Dwi. 2006. Pengaruh Pengalaman Terhadap Peningkatan Keahlian Auditor dalam Bidang Auditing. Skripsi Universitas Islam Indonesia. Yogyakarta.

Fullerton, Rosemary., and Durtschi, Cindy. 2003. The Effect of Professional Skepticism on The Fraud Detection Skills of Internal Auditors. Working Paper Series. March 5, 2012. 
Ghozali, Imam. 2012. Aplikasi Analisis Multivariate dengan Program IBM SPSS 17”. Semarang: UNDIP.

Gusti, Maghfirrah dan Syahril, Ali. 2008. Hubungan Skeptisisme Profesional dan Situasi Etika, Pengalaman serta Keahlian Audi dengan Ketepatan Pemberian Opini Auditor Oleh Akuntan Publik. Simposium Nasional Akuntansi XI, Universitas Andalas. Padang.

Halim, Abdul. 2008. Auditing (Dasar-dasar Audit Laporan Keuangan). Edisi Keempat. Jilid 1. Sekolah Tinggi Ilmu Manajemen YKPN, Yogyakarta.

Herusetya, Antonius. 2007. Kewajiban Hukum Bagi Akuntan Publik: Resiko Profesional yang Semakin Meningkat. Jurnal Akuntansi dan Keuangan. Vol.1, No.1. Hal 1-17.

Hogarth. R. M., dan H.J Einhorn., 1992., Order Effects in Belief Updating: The BeliefAdjustment Mode., Cognitive Psychology 24: 1 - 55.

Idris, Seni Fitriani. 2012. Pengaruh Tekanan Ketaatan, Kompleksitas Tugas, Pengetahuan dan Persepsi Etis Terhadap Audit Judgment. Skripsi Universitas Diponegoro. Semarang.

Indriantoro, Supomo. 2002, Metodologi Penelitian Bisnis untuk Akuntansi dan Manajemen, Edisi Pertama, BPFE, Yogyakarta.

Iskandar, Takiah dan Sanusi, Mohd,. 2011. Assesing the effecys of self-efficacy and task complexity on internal control audit judgment. Asian Academy of management journal of accounting and finance, AAMJAF. Vol.7. Hal 18-24.

Jamilah, Siti, Zaenal Fanani, dan Grahita Chandrarin. 2007. Pengaruh Gender, Tekanan Ketaatan, dan Kompleksitas Tugas terhadap Audit Judgment. Simposium Nasional Akuntansi X Unhas Makassar.

Januarti, Indira dan K. Sabrina Rr. 2011. Pengaruh Pengalaman, keahlian, situasi audit, etika dan gender terhadap ketepatan pemberian opini auditor melalui skeptisme profesional auditor. Journal Sistem Informatika, Etika dan Auditing. Hal 1-12

Jamilah, Siti, Zaenal Fanani dan Grahita Chandrarin, 2007. Pengaruh gender, tekanan ketaatan, dan kompleksitas tugas terhadap audit judgment. Simposium Nasional Akuntansi X. Universitas Hasanudin. Makasar. 26-28 Juli

Kamus Besar Bahasa Indonesia. Arti Kata Skeptisme. http://kbbi.web.id/.

Kamus Besar Bahasa Indonesia. Arti Kata Pengalaman. http://kbbi.web.id/.

Kelly, Harold H.1973. The Processes of Causal Attribution. American Psycologist. February 1973 pp.107-128.

Kompas.com. Diterbitkan 14 November 2013" Korupsi tawas, mantan Direktur PDAM Bengkulu divonis 4 tahun". (http://poskotanews.com/2013/04/05/mantan-dirut-pdamkarawang-akhirnya-ditahan). [diakses 5 Februari 2017

Lestari, Rika Ayu.2015. Pengaruh skeptisme, pengalaman audit dan self-efficacy terhadap audit judgment. Jakarta. Skripsi FE Universitas Syarif Hidayatullah. Jakarta

McClelland, D. C. 1987. Human Motivation. New York: The Press Syndicate of The University of Chambridge.

Mulyadi. 2002. Auditing. Edisi 6. Jakarta: Salemba Empat.

Nadhiroh, Siti Asih. 2010. Pengaruh Kompleksitas Tugas, Orientasi Tujuan dan Self efficacy Terhadap Kinerja Auditor dalam pembuatan keputusan audit judgement. Skripsi Universitas Diponegoro Semarang.

Puspa, Enggar Diah. 2007. Pengaruh Persuasi atas Preferensi Klien dan Pengalaman Audit Terhadap Pertimbangan Auditor dalam Mengevaluasi Bukti Audit. The $1^{\text {st }}$ Accounting Conference. Hal 1-19. 
PENGARUH SKEPTISME, PENGALAMAN AUDITOR DAN SELF EFFICACY TERHADAP

Wiwien Maryani dan Fitrawati Ilyas

Praditaningrum, Anugrah Suci 2012. Analisis Faktor-Faktor Yang Berpengaruh Terhadap Audit Judgement. Skripsi Fakultas Ekonomi dan Bisnis Universitas Diponegoro.

Prihandono A, Utama. 2012. Hubungan Skeptisme Professional Auditor, Situasi Audit, Independensi, etika, Keahlian dan Pengalaman dengan Keputusan Pemberian Opini Audit Oleh Auditor. Fakultas Ekonomi dan Bisnis Universitas Diponegoro, Semarang.

Rai, I Gusti Agung. 2008. Audit kinerja pada sektor public. Jakarta. Salemba Empat.

Radar Karawang. Diterbitkan 15 maret 2013. "Bekas Direktur PDAM Jadi Tersangka Korupsi”.(http://www.radar-karawang.com/2013/03/bekas-direktur-pdam-jaditersangka.html). [diakses 5 februari 2017

Rizkiyana, Dellia Eka. 2013. Pengaruh Pengalaman audit dan preferensi klien terhadap audit judgement dengan kredibilitas klien sebagai variabel moderating. Skripsi Universitas Islam Negeri syarif hidayatullah Jakarta.

Rusyanti, Rina. 2010. Pengaruh Sikap Skeptisme Auditor, Profesionalisme Auditor, dan Tekanan Anggaran Waktu terhadap Kualitas Audit. Skripsi Tidak Dipublikasikan. Universitas Islam Syarif Hidayatullah, Jakarta.

Sabaruddinsah. 2007. Pengaruh Gender, Pengalaman Auditor, Dan Kompleksitas Tugas Terhadap Audit Judgment. Universitas Islam Paradigma. Bekasi.

Sekaran, Uma. 2006. Metodologi Penelitian untuk Bisnis Buku 1 dan 2 Edisi Pertama. Jakarta: Salemba Empat.

Siegel G, Marconi, Ramanauskas H, 1989. Behavioral Accounting. Cincinanti Ohio: SouthWestern Publishing Co.

Susetyo, Budi. 2009. Pengaruh Pengalaman Audit Terhadap Pertimbangan Auditor dengan Kredibilitas Klien Sebagai Variabel Moderating. Tesis Universitas Diponegoro. Semarang.

Soekrisno, Agoes. 2012. Auditing Petunjuk Praktis Pemeriksaan Akuntan oleh Akuntan Publik. Edisi 4. Buku 1. Salemba Empat, Jakarta.

Tuanakota, Theodorus M. 2013. Audit Berbasis ISA (International Standards on Auditing). Salemba Empat, Jakarta.

Walgito, Bimo. 2002. Pengantar Psikologi Umum. Yogyakarta: Andi Offset.

Wijayantini, Kadek Ayu. 2014. Pengaruh Tekanan Ketaatan Kompleksitas Tugas dan Self Efficacy Terhadap Audit Judgment. Fakultas Ekonomi Universitas Pendidikan Ganesha.

Yustrianthe, Rahmawati Hanny. 2012. Beberapa Faktor yang Mempengaruhi Audit Judgment Auditor Pemerintah, Jurnal Dinamika Akuntansi . Vol. 4, No. 2, Hal: 72-82. 